THE FUTURE OF CULTURAL MINORITIES 
Also by the editors

Antony E. Alcock

THE HISTORY OF THE SOUTH TYROL QUESTION

HISTORY OF THE INTERNATIONAL LABOUR ORGANISATION

Brian K. Taylor

THE WESTERN LACUSTRINE BANTU

John M. Welton (co-editor with Jack Walton)

RATIONAL CURRICULUM PLANNING 


\section{THE FUTURE OF \\ CULTURAL \\ MINORITIES}

Edited by

Antony E. Alcock

Brian K. Taylor

John M. Welton

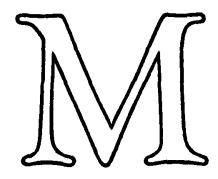


Selection and editorial matter (C) Antony E. Alcock, Brian K. Taylor, John M. Welton 1979

Chapter I (C) Brian K. Taylor I 979 Chapter 2 (C) Glanville Price 1979 Chapter 3 (C) Margaret B. Sutherland I 979 Chapter 4 (C) F. Y. St. Leger I 979 Chapter 5 (C) Terence O'Brien 1979 Chapter 6 (C) Antony E. Alcock 1979 Chapter 7 (C) The Minority Rights Group 1979 Chapter 8 (C) K. R. Gladdish 1979

Softcover reprint of the hardcover 1st edition 1979

All rights reserved. No part of this publication may be reproduced or transmitted, in any form or by any means, without permission

First published 1979 by

THE MACMILLAN PRESS LTD

London and Basingstoke Associated companies in Delhi Dublin Hong Kong Johannesburg Lagos Melbourne New York Singapore Tokyo

Typeset in Great Britain by VANTAGE PHOTOTYPESETTING CO. LTD SOUTHAMPTON AND LONDON

\section{British Library Cataloguing in Publication Data}

The future of cultural minorities

I. Minorities

I. Alcock, Anthony Evelyn II. Taylor, Brian K III. Welton, John $301.45^{\prime} \mathrm{I}$ $\mathrm{HT}_{1} 5^{23}$

ISBN 978-1-349-04264-7 ISBN 978-1-349-04262-3 (eBook) DOI 10.1007/978-1-349-04262-3

This book is sold subject to the standard conditions of the Net Book Agreement 


\section{Contents}

Acknowledgements vi

Notes on the Contributors vii

Introduction I

I Culture: Whence, Whither and Why? 9 Brian K. Taylor

2 The Present Position and Viability of Minority Languages 30 Glanville Price

3 Comparative Perspectives on the Education of Cultural Minorities

Margaret $\boldsymbol{B}$. Sutherland

4 The Mass Media and Minority Cultures 63

F. Y. St Leger

5 Economic Support for Minority Languages 82 Terence O'Brien

6 The Development of Governmental Attitudes to Cultural

Minorities in Western Industrial States Antony E. Alcock

7 The Role of Law in Relation to Minority Groups Claire Palley

8 The Political Dynamics of Cultural Minorities K. R. Gladdish

9 Conclusions

Select Bibliography 


\section{Acknowledgements}

In May 1977 the editors held a weekend seminar on 'The Future of Cultural Minorities' at the Richardson Institute for Peace and Conflict Research. Following the seminar the general form of this book emerged and the editors would like to record their gratitude to the Director of the Institute, Michael Nicholson, and to the Joseph Rowntree Charitable Trust for making the seminar possible. They also wish to thank the following people who contributed to the seminar: Ken Gladdish, Lars Mosesson, Claire Palley, Joseph Pickvance, Frances Pinter, Robert Ramsay, and Andrew Trew.

Several colleagues at the New University of Ulster contributed to our thinking about this book, among them Derek Birrell.

We thank all the contributors to this book for their interest, cooperation, and willingness to keep almost impossible deadlines.

Finally we would like to thank Nicholas Gillett whose gift it is to sow seeds. 


\section{Notes on the Contributors}

Antony E. Alcock is Senior Lecturer and Head of West European Studies at the New University of Ulster, Coleraine. He previously held positions with the International Labour Organisation, the United Nations Institute for Training and Research, the European Commission and the European Economic and Social Council. He has written extensively on minority protection.

Ken Gladdish is Senior Lecturer in Politics at the University of Reading. He was formerly an Administrative Officer in Uganda. He has particular interests in multicultural problems.

Terence A. O'Brien is Lecturer in Economics at the New University of Ulster, Coleraine. He is engaged in a study of the role of co-operatives in the economic and social development of contemporary Ireland.

Claire Palley is Professor of Law at the University of Kent, Canterbury, and is particularly interested in constitutional and family law.

Glanville Price is Professor of Romance Languages at the University College of Wales, Aberystwyth. His particular interest lies in minority languages, and he has published The Present Position of Minority Languages in Western Europe: a Selective Bibliography.

Frederick Y. St Leger is Lecturer in Social Administration at the New University of Ulster, Coleraine. His recent research covers the African press in South Africa. 


\section{viii}

Margaret B. Sutherland is Professor of Education at the University of Leeds. She has special interests in comparative education.

Brian K. Taylor is Senior Lecturer in Social Administration at the New University of Ulster, Coleraine, and has previously held university posts at Swansea and Adelaide. He was formerly a social anthropologist and Community Development Officer in East Africa. He is editor of Community Development Journal.

John M. Welton is Lecturer in Educational Development and Administration at the New University of Ulster, Coleraine, and his research interests lie in the relationships between schools and the community. 